\title{
Synthesis and swelling behavior of polyurethane networks based on hyperbranched polymer
}

\author{
Jasna V. Džunuzović ${ }^{1}$, Marija V. Pergal ${ }^{1}$, Slobodan Jovanović ${ }^{2}$, Vesna V. Vodnik ${ }^{3}$ \\ ${ }^{1}$ Institute of Chemistry, Technology and Metallurgy (ICTM) - Center of Chemistry, University of Belgrade, \\ Belgrade, Serbia \\ ${ }^{2}$ Faculty of Technology and Metallurgy, University of Belgrade, Belgrade, Serbia \\ ${ }^{3}$ Institute of Nuclear Science "Vinča", University of Belgrade, Belgrade, Serbia
}

\begin{abstract}
A series of six polyurethane (PU) networks was synthesized from Boltorn ${ }^{\circledR}$ hydroxy-functional hyperbranched polyester (HBP) of the second pseudo generation as a cross-linking agent, $\alpha, \omega$-dihydroxy-(ethylene oxide-poly(dimethylsiloxane)-ethylene oxide) (EO-PDMS-EO) and 4,4'-methylenediphenyl diisocyanate, by two-step polymerization in solution. Each sample of the prepared PUs had different EO-PDMS-EO content. The chemical structure of the synthesized networks was analyzed by FTIR spectroscopy. The influence of the EO-PDMS-EO content and type of the solvent on the swelling behavior of the PUs in 2-propanol and toluene was investigated. During the swelling measurements, a certain amount of sol fractions was extracted from the PUs by solvents. According to the ${ }^{1} \mathrm{H}-\mathrm{NMR}$ results, sol fractions were mainly composed of the soluble hyperbranched $\mathrm{PU}$, formed during the polymerization by partial modification of the end hydroxyl groups of HBP with NCO-terminated prepolymer synthesized in the first step of the reaction. Chains of the so reacted prepolymer can then fold back and form cyclic products by reaction of the free -NCO group from the NCO-terminated prepolymer with free $-\mathrm{OH}$ group of HBP. As the EO-PDMS-EO content increases the amount of the sol fractions and swelling degree also increased, indicating that networks with lower EO-PDMS-EO content are more cross-linked and have higher solvent resistance.
\end{abstract}

Keywords: polyurethane; hyperbranched polyester; poly(dimethylsiloxane); swelling behavior.

\author{
SCIENTIFIC PAPER \\ UDC 678.664:66.095.261 \\ Hem. Ind. 65 (6) 637-644 (2011) \\ doi: 10.2298/HEMIND110902071D
}

Available online at the Journal website: http://www.ache.org.rs/HI/

Polyurethanes (PUs) based on hyperbranched polymers attracted significant attention over the past years [1-7]. The reasons for that lie in the specific, compact, three-dimensional structure of hyperbranched polymers, their low cost synthesis, presence of a large number of end functional groups and unique properties such as low viscosity in solution and melt, lack of entanglements, high solubility in numerous solvents, good compatibility with different materials, etc. Additionally, properties of hyperbranched polymers can be enhanced and tailored by modification of all or one part of their end groups. Especially attractive is the application of hyperbranched macromolecules as crosslinkers in the synthesis of PUs [1-3,6,7]. Hyperbranched polymers which were mostly used for the preparation of different types of polyurethane networks are Boltorn $^{\circledast}$ aliphatic hydroxy-functional hyperbranched polyesters (HBPs), based on 2,2-bis(hydroxymethyl)propio-

Correspondence: J. V. Džunuzović, Institute of Chemistry, Technology and Metallurgy (ICTM) - Center of Chemistry, University of Belgrade, Studentski trg 12-16, 11000 Belgrade, Serbia.

E-mail: jasnav2002@yahoo.com

Paper received: 2 September, 2011

Paper accepted: 26 September, 2011 nic acid as monomer and a tetrafunctional ethoxylated pentaerythrytol core $[1,6,7]$. Chemical networks of such PUs are produced in a controlled way using Boltorn HBP, while the hydrogen bonding between the carbonyl and amine groups of adjacent chains leads to the formation of physical networks. The presence of the cross-links in PUs introduces swelling ability and rubber elasticity.

The use of poly(dimethylsiloxane)s as macrodiols for the synthesis of PUs based on Boltorn ${ }^{\circledR}$ HBPs was for the first time presented in our previous paper [8]. Poly(dimethylsiloxane)s are intriguing class of polymers which have very low glass transition temperature (-123 ${ }^{\circ} \mathrm{C}$ ), good thermal, oxidative, hydrolytic and UV stability, low surface tension and energy, low moisture and good gas permeability, etc. These polymers have been frequently used for the synthesis of different PUs in order to improve their thermal and surface properties, water and fire resistance $[9,10]$. Our first attempt to synthesize PU networks using $\alpha, \omega$-dihydroxy-(ethylene oxide-poly(dimethylsiloxane)-ethylene oxide) (EO-PDMS-EO), 4,4'-methylenediphenyl diisocyanate (MDI) and Boltorn ${ }^{\circledR}$ HBP of the second pseudo generation $(\mathrm{BH}-20)$ in melt have shown that applied synthetic procedure leads to the formation of a heterogeneous net- 
work [8]. Therefore, in the present study we used a catalyzed two-step polymerization process in solution in order to improve the compatibility of all reactants, to prevent undesired macroscopic phase separation and to obtain polyurethane networks with good thermal and surface properties for possible application as coatings. Six PU networks with different macrodiol content were synthesized from EO-PDMS-EO, BH-20 and MDI. A detailed description of the synthetic procedure and reaction mixture calculations are given. The chemical structure of the obtained polymers was analyzed by FTIR. The influence of the EO-PDMS-EO content on the swelling behavior in two different solvents was investigated. Sol fractions extracted from the synthesized PUs by the solvent were examined by ${ }^{1} \mathrm{H}-\mathrm{NMR}$.

\section{EXPERIMENTAL}

\section{Materials}

Boltorn ${ }^{\circledR}$ hydroxy-functional aliphatic hyperbranched polyester of the second ( $\mathrm{BH}-20)$ pseudo generation was kindly supplied by Perstorp Specialty Chemicals $A B$ (Sweden) and dried at $50{ }^{\circ} \mathrm{C}$ under vacuum for two days before use. From the number average molecular weight of the $\mathrm{BH}-20$, determined by vapor pressure osmometry $\left(M_{\mathrm{n}}=1340 \mathrm{~g} / \mathrm{mol}\right)$ [11] and hydroxyl number $(H N=501.1 \mathrm{mg} \mathrm{KOH} / \mathrm{g})[11,12]$ the functionality $(f=12$ ) was calculated. $\alpha, \omega$-Dihydroxy-(ethylene oxide-poly(dimethylsiloxane)-ethylene oxide) was supplied by ABCR. Before the synthesis, EO-PDMS-EO was dried over molecular sieves $(0.4 \mathrm{~nm})$. Using the ${ }^{1} \mathrm{H}-\mathrm{NMR}, M_{\mathrm{n}}$ was calculated and the obtained value of $1200 \mathrm{~g} / \mathrm{mol}$ was used for the calculations of the reaction mixtures [13]. 4,4'-Methylenediphenyl diisocyanate (MDI) was supplied by Aldrich (purity $>98 \%$ ) and used as received. The content of -NCO groups in MDI was determined by the titration method (33.6wt\%) [14]. The catalyst stannous octanoate, $\left(\mathrm{Sn}(\mathrm{Oct})_{2}\right)$ was supplied from Aldrich and used as diluted solution in anhydrous $\mathrm{N}$-methyl-2-pyrrolidone (NMP). NMP was purchased from Across, distilled and kept over molecular sieves $(0.4 \mathrm{~nm})$ prior to use. Tetrahydrofuran (THF) was purchased from J. T. Baker, dried over lithium aluminum hydride and distilled before use. Toluene was supplied by Lach-ner and used as received. 2-Propanol was purchased from Zorka Pharma (Šabac) and used as received.

\section{Synthesis of the polyurethanes}

Six new polyurethanes (PU2-60, PU2-50, PU2-40, PU2-30, PU2-20 and PU2-15) based on the BH-20, EO-PDMS-EO and MDI were synthesized by a two-step polymerization in solution. The chemical structures of the used reactants are given in Figure 1 . The mixture NMP/THF was used as solvent. The last two numbers in the name of the prepared samples represent weight percent of the EO-PDMS-EO. The total molar ratio of $-\mathrm{NCO}$ and $-\mathrm{OH}$ groups was set to the constant value of 1.05 [14]. All PUs were synthesized using the same procedure. Here the synthesis of PU2-40 is described as an example. Adequate amount of EO-PDMS-EO (2.9 $\mathrm{mmol}, 3.50 \mathrm{~g})$ dissolved in the mixture of solvents NMP/THF $(24.2 \mathrm{ml} / 3.8 \mathrm{ml})$ was placed in a four-neck round-bottom flask located in a silicone oil bath and connected to an inlet for dry argon, a mechanical stirrer, a dropping funnel and a reflux condenser. Then MDI (12.7 mmol, $3.18 \mathrm{~g}$ ) was added into the flask, the reaction mixture was stirred and heated to $40{ }^{\circ} \mathrm{C}$ under an argon atmosphere. When the temperature of $40{ }^{\circ} \mathrm{C}$ was reached, catalyst solution in NMP $(0.28 \mathrm{ml} ; 0.15$ mol\% based on the EO-PDMS-EO) was added [14]. After 30 minutes of continuous stirring at $40{ }^{\circ} \mathrm{C}$, the NCO-terminated prepolymer was obtained [14]. A standard dibutylamine back-titration method was applied in order to control the content of -NCO groups [15]. Then, $\mathrm{BH}-20$ (1.5 mmol, $2.06 \mathrm{~g})$ dissolved in NMP (19.2 ml) was added drop-wise into the reaction mixture. The reaction mixture was stirred for another $10 \mathrm{~min}$ at 40

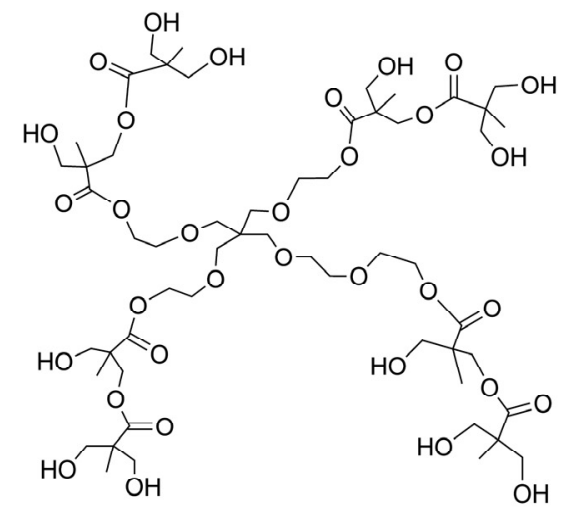

Boltorn ${ }^{\circledR}$ hyperbranched polyester

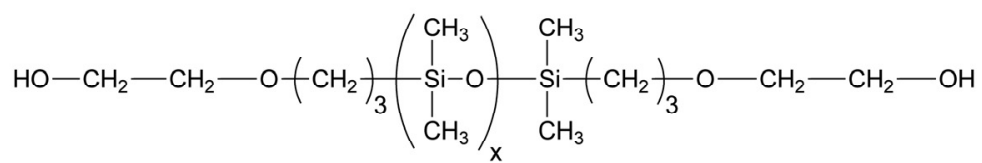

EO-PDMS-EO

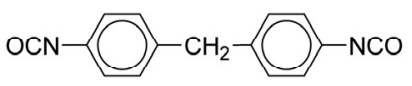

Figure 1. The chemical structures of the reactants used for the synthesis of polyurethanes. 
${ }^{\circ} \mathrm{C}$ and then cast in a round glass, previously lubricated with silicone oil. The cross-linking reaction was continued in a force-draft oven at $80^{\circ} \mathrm{C}$ for $45 \mathrm{~h}$ and at 110 ${ }^{\circ} \mathrm{C}$ for $1 \mathrm{~h}$, and finally $10 \mathrm{~h}$ at $50{ }^{\circ} \mathrm{C}$ in a vacuum oven. The synthesized PU networks were obtained as brown films with a thickness of about $2 \mathrm{~mm}$. Before any testing, all synthesized PUs were kept in desiccator at room temperature for two weeks.

\section{Characterization}

FTIR spectra were recorded with an attenuated total reflection (ATR) mode on a NICOLET 380 FTIR spectrometer. For each measurement a resolution of $4 \mathrm{~cm}^{-1}$ and the scanning range from 400 to $4000 \mathrm{~cm}^{-1}$ were applied.

Swelling measurements of the synthesized polyurethanes were performed at room temperature using two different solvents (toluene and 2-propanol). Test samples for swelling experiments were squares, cut from the cast films, weighing about $0.2 \mathrm{~g}$. The PU samples were immersed in solvent. Periodically, these specimens were removed from the solvent and weighed after removal of the excess of solvent from the sample using filter paper. This was repeated until constant weight (equilibrium swelling). The average value of three parallel swelling experiments in every solvent for each sample was used. The swelling degree, $q$, was calculated using gravimetric method:

$$
q=\frac{m-m_{0}}{m_{0}}
$$

where $m$ and $m_{0}$ are the sample weights after and before swelling, respectively. After swelling samples were dried in vacuum oven until constant weight and the weight of the gel fraction, $m_{\mathrm{g}}$, was measured. The percentage of the sol fractions was calculated using the Eq. (2):

$$
\text { sol\% }=100 \frac{m_{0}-m_{\mathrm{g}}}{m_{0}}
$$

${ }^{1} \mathrm{H}$ NMR spectra of the sol fractions were obtained at $200 \mathrm{MHz}$ using Varian-Gemini-200 spectrometer. Measurements were performed at $25^{\circ} \mathrm{C}$ using DMSO$-d_{6}$ as solvent, while the chemical shifts are presented on the $\delta$ scale relative to the DMSO- $d_{6}$ signal. Solutions were prepared at $50{ }^{\circ} \mathrm{C}$ at a concentration of $10 \%$ $(w / v)$. For this purpose, sol fractions which were extracted from the synthesized PUs by the solvent were collected by evaporation of the solvent.

\section{RESULTS AND DISCUSSION}

Six polyurethane networks of different EO-PDMSEO content based on the second pseudo generation Boltorn ${ }^{\circledR} \mathrm{HBP}$, EO-PDMS-EO and MDI (Figure 1) were synthesized according to the procedure described in the experimental part of this work. The adequate amounts of all reactants were calculated starting from the fact that during the synthesis the total molar ratio of $-\mathrm{NCO}, n_{\mathrm{NCO}}$, and $-\mathrm{OH}, n_{\mathrm{OH}}$, groups was set to the constant value:

$$
\frac{n_{\mathrm{NCO}}}{n_{\mathrm{OH}}}=\frac{2 n_{\mathrm{MDI}}}{2 n_{\text {EO-PDMS-EO }}+12 n_{\mathrm{BH}-20}}=1.05
$$

where $n_{\mathrm{MDI}}, n_{\text {EO-PDMS-EO }}$ and $n_{\mathrm{BH}-20}$ represent number of moles of MDI, EO-PDMS-EO and $\mathrm{BH}-20$, respectively. The Eq. (3) can also be written in the following manner:

$$
n_{\mathrm{MDI}}=1.05 \cdot\left(n_{\mathrm{EO}-\mathrm{PDMS}-\mathrm{EO}}+6 n_{\mathrm{BH}-20}\right)
$$

The EO-PDMS-EO content was calculated using Eq. (5):

$$
\mathrm{EO}-\mathrm{PDMS}-\mathrm{EO} \%=100 \frac{m_{\text {EO-PDMS-EO }}}{m_{\text {EO-PDMS-EO }}+m_{\mathrm{BH}-20}+m_{\mathrm{MDI}}}
$$

where $m_{\mathrm{MDI}}, m_{\text {EO-PDMS-EO }}$ and $m_{\mathrm{BH}-20}$ represent weights of MDI, EO-PDMS-EO and BH-20, respectively. Since molecular weights of all reactants, EO-PDMS-EO content and starting weight of the EO-PDMS-EO are known, necessary amounts of $\mathrm{BH}-20$ and $\mathrm{MDI}$ can be easily calculated using the combination of the Eqs. (4) and (5).

The confirmation of the chemical structure of the synthesized PUs was obtained by FTIR spectroscopy. Figure 2 shows FTIR spectra of $\mathrm{BH}-20$ and two selected PUs. Several characteristic absorption bands appear in the FTIR spectrum of $\mathrm{BH}-20$ : a broad absorption band at $3300 \mathrm{~cm}^{-1}$ which corresponds to the hydroxyl groups, peak at $1723 \mathrm{~cm}^{-1}$ which corresponds to the carbonyl ester groups, absorption bands characteristic for the ether groups at $1010-1120 \mathrm{~cm}^{-1}, \mathrm{C}-\mathrm{O}$ linkage of ester groups at $1040-1210 \mathrm{~cm}^{-1}$ and absorption bands ascribed to the $-\mathrm{CH}_{2}-$ and $-\mathrm{CH}_{3}$ groups at $2900-3000 \mathrm{~cm}^{-1}$. From the FTIR spectra of the PU networks it can be observed that characteristic stretching frequencies of the synthesized PUs appear at 3306 (hydrogen-bonded -NH stretching vibrations), 1258 (amide II band), 1537 (amide III band), 790 ( $\mathrm{Si}-\mathrm{CH}_{3}$ linkage), at around 2961, 2903 and 2875 (symmetric and asymmetric $-\mathrm{CH}_{2}$ - and $-\mathrm{CH}_{3}$ groups) and at 1596 and $1412 \mathrm{~cm}^{-1}$ (aromatic $\mathrm{C}=\mathrm{C}$ ). The peaks corresponding to the $\mathrm{C}=\mathrm{O}$ stretching vibrations can be observed in the region 1650-1735 $\mathrm{cm}^{-1}$. The absorption bands, which can be observed at around 1015 and $1080 \mathrm{~cm}^{-1}$, represent overlapped bands of Si-O-Si and $\mathrm{C}-\mathrm{O}-\mathrm{C}$ groups. In the FTIR spectra of PUs bands corresponding to the $-\mathrm{NCO}\left(2260 \mathrm{~cm}^{-1}\right)$ and hydroxyl groups $\left(3300 \mathrm{~cm}^{-1}\right)$ from $\mathrm{BH}-20$, were not detected.

Swelling behavior of the prepared PUs was investigated in two solvents with different solubility parameters: 2-propanol $\left(\delta_{2 \text {-Propanol }}=23.5 \mathrm{~J}^{1 / 2} / \mathrm{cm}^{3 / 2}\right)$ and toluene 


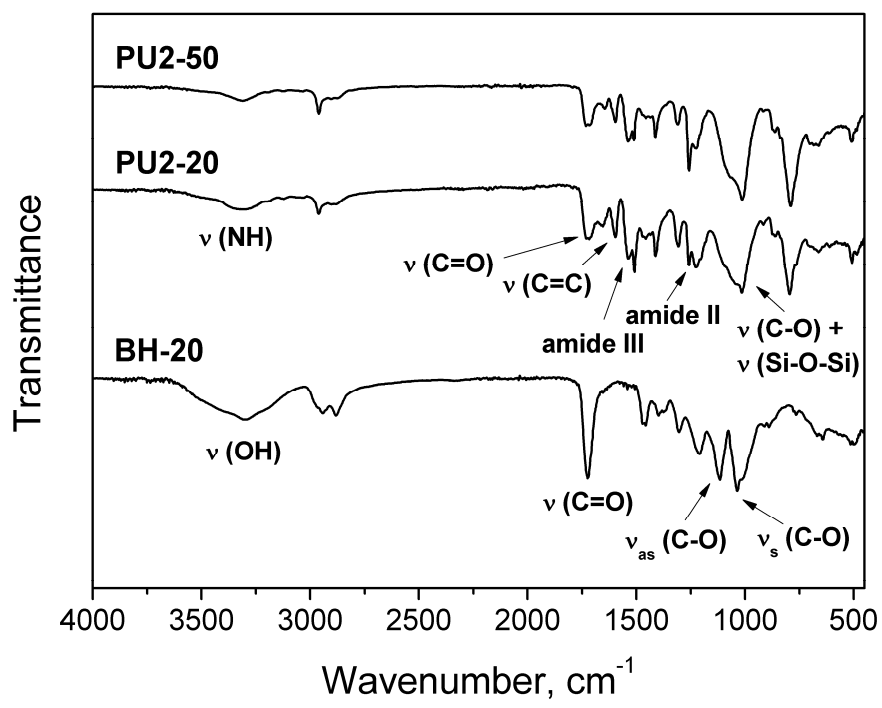

Figure 2. FTIR spectra of the BH-2O and selected synthesized polyurethanes.

$\left(\delta_{\text {Toluene }}=18.2 \mathrm{~J}^{1 / 2} / \mathrm{cm}^{3 / 2}\right)[16]$. The results presented in Figures 3 (2-propanol) and 4 (toluene) show that swelling degree of these PU networks started to decrease after reaching maximum value, $q_{\max }$, because of the extraction of the sol fraction. The only exception from this was the swelling degree of PU2-15 in 2-propanol, which increased gradually with time. The presence of the sol fractions indicates that these samples do not contain the maximum number of cross-links because certain amount of the soluble portions is also present in their structure. With increasing the EO-PDMS-EO content the amount of the extracted sol fractions also increased (Table 1), indicating that the presence of larger quantities of the cross-linking agent enabled higher degree of cross-linking. Swelling time necessary to reach $q_{\max }$ increases with the decrease of the EO-PDMS-EO content. Maximum values of the swelling degree were achieved in toluene much faster than in 2 - -propanol. After reaching $q_{\max }$, swelling degree of the PUs with higher EO-PDMS-EO content sharply decreased in both solvents. Furthermore, equilibrium swelling degree, $q_{\text {eq, }}$ was in toluene achieved for all samples after approximately $48 \mathrm{~h}$, while in 2-propanol $q_{\text {eq }}$ for most synthesized PUs it was reached after approximately $73 \mathrm{~h}$. Values of $q_{\text {eq }}$ determined for the synthesized PU networks are listed in Table 1. It can be observed that they decrease with the decrease of the EO-PDMS-EO content, indicating that samples with lower EO-PDMS-EO content are more cross-linked and have higher solvent resistance. Additionally, results presented in Table 1 show that determined values of the swelling degree of the synthesized PUs are somewhat higher in 2-propanol than in toluene probably as a consequence of their different solubility parameters.

In order to establish the chemical composition of the sol fractions, the soluble portion extracted from the

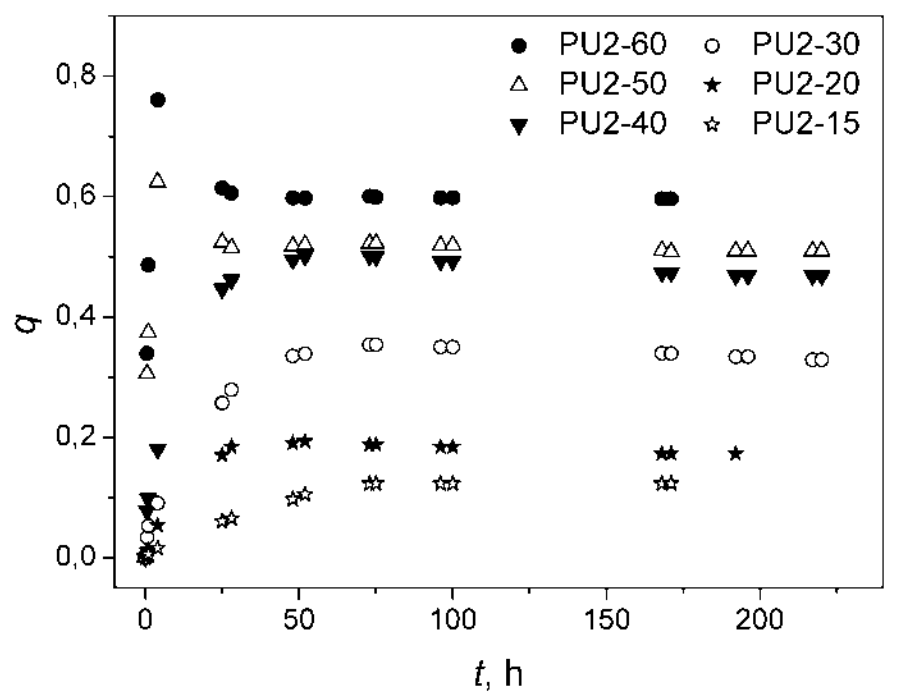

Figure 3. Swelling degree of the synthesized polyurethanes obtained in 2-propanol vs. time. 


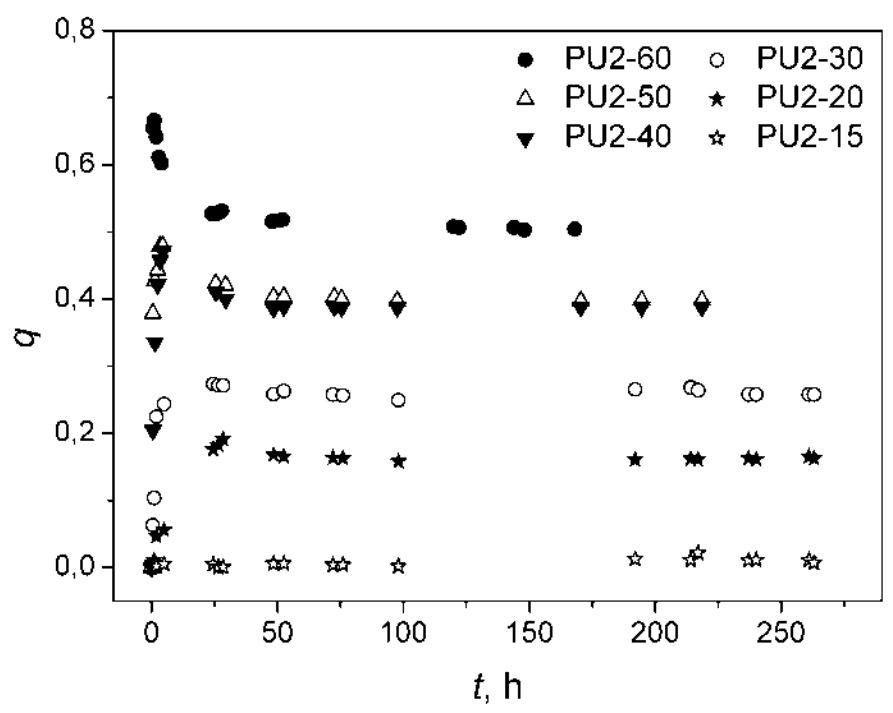

Figure 4. Swelling degree of the synthesized polyurethanes obtained in toluene vs. time.

Table 1. Percent of the sol fractions, sol\%, and equilibrium swelling degree, $q_{\text {eq }}$ obtained in 2-propanol and toluene of the synthesized polyurethane networks

\begin{tabular}{lcccc}
\hline \multirow{2}{*}{ Sample } & \multicolumn{3}{c}{ Sol\% } & \\
\cline { 2 - 5 } & 2-Propanol & Toluene & 2-Propanol \\
\hline PU2-60 & 21.40 & 18.19 & 0.598 & Toluene \\
PU2-50 & 11.72 & 9.61 & 0.510 & 0.504 \\
PU2-40 & 7.48 & 8.23 & 0.468 & 0.398 \\
PU2-30 & 2.17 & 5.78 & 0.328 & 0.173 \\
PU2-20 & 1.86 & 4.19 & 0.258 \\
PU2-15 & - & 0.27 & 0.123 & 0.007 \\
\hline
\end{tabular}

synthesized PU networks by the toluene was collected after the evaporation of the solvent and examined by ${ }^{1} \mathrm{H}$ NMR spectroscopy. In Figure 5 and Figure $6{ }^{1} \mathrm{H}-\mathrm{NMR}$ spectra of the PU2-60 and PU2-30 sol fractions are given, respectively. In the ${ }^{1} \mathrm{H}-\mathrm{NMR}$ spectrum of the PU2-60 sol fraction (Figure 5) a signal at -0.04 ppm belongs to the protons of the methyl group connected to a silicon $\left(\mathrm{Si}-\mathrm{CH}_{3}\right)$, at $0.44 \mathrm{ppm}$ to the $\mathrm{Si}-\mathrm{CH}_{2}$ protons, at $1.45 \mathrm{ppm}$ to the central $-\mathrm{CH}_{2}$ - protons of the EO-PDMS-EO propylene groups and at $3.45 \mathrm{ppm}$ to the $-\mathrm{CH}_{2}-$ protons from the propylene group of the EO-PDMS-EO attached to the oxygen [17] and protons from the methylene groups attached to unreacted hydroxyl groups $\left(\mathrm{CH}_{2}-\mathrm{OH}\right)$ of $\mathrm{BH}-20$ [18]. The peak at 4.12 ppm results from the protons of $\mathrm{CH}_{2}-\mathrm{OR}$ groups of $\mathrm{BH}$ -20 and methylene protons of ethylene oxide attached to the ether oxygen, while signals at 4.64 and $4.95 \mathrm{ppm}$ are due to the protons of the $-\mathrm{OH}$ from the terminal and linear units of $\mathrm{BH}-20$, respectively $[18,19]$. A signal at $4.95 \mathrm{ppm}$ is overlapped with signal of methylene protons from ethylene oxide attached to the urethane group. Methyl protons which belong to terminal, linear and dendritic units of $\mathrm{BH}-20$ resonate at $1.03,1.08$ and
$1.16 \mathrm{ppm}$, respectively [19]. The peak at $3.78 \mathrm{ppm}$ is assigned to the $-\mathrm{CH}_{2}-$ protons from the MDI residues, while aromatic protons of MDI appear at 7.06 and 7.32 $\mathrm{ppm}$. Two peaks at 8.56 and $9.48 \mathrm{ppm}$ result from the urethane protons $[13,17]$. In the ${ }^{1} \mathrm{H}-\mathrm{NMR}$ spectrum of PU2-30 (Figure 6) and other extracted sol fractions (not presented) the same signals can be observed, except two signals belonging to the $\mathrm{NH}$ urethane protons which were not detected. The results obtained by ${ }^{1} \mathrm{H}$ -NMR spectroscopy show that sol fractions of the synthesized PUs are mainly composed of hyperbranched polyurethane, which was formed during the polymerization. These soluble compounds are probably composed by partial end-capping of $-\mathrm{OH}$ groups of $\mathrm{BH}-20$ by NCO-terminated prepolymer. Furthermore, it is possible that during the curing process the chains of the so reacted prepolymer fold back and form cycles of different sizes by reaction of the free -NCO group from the prepolymer with another free -OH group of hyperbranched polyester. In this manner, $-\mathrm{NCO}$ and $-\mathrm{OH}$ groups will be blocked and disabled to participate further in the cross-linking reaction. Additionally, the presence of the $-\mathrm{OH}$ protons in the ${ }^{1} \mathrm{H}-\mathrm{NMR}$ spectra 


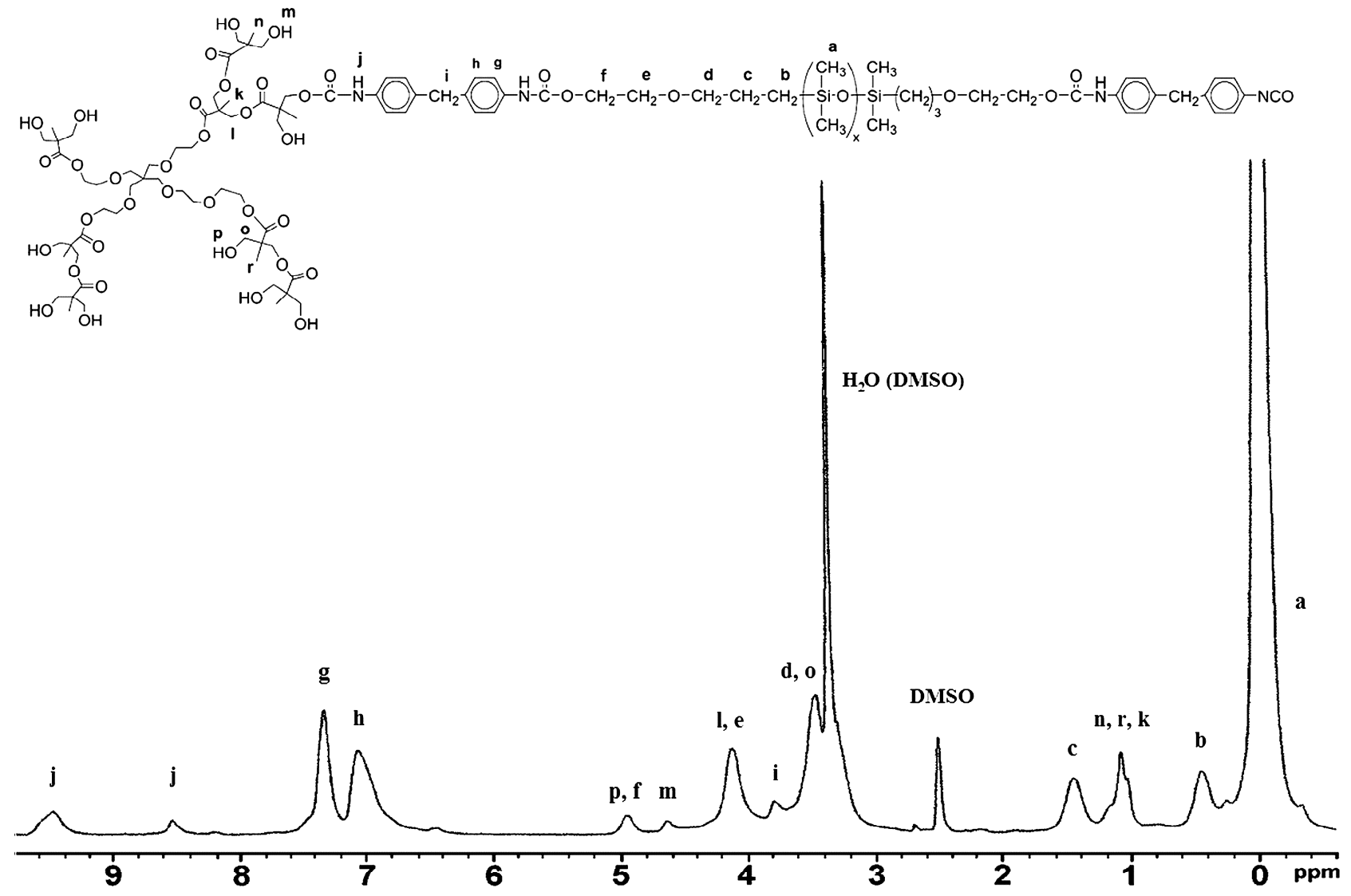

Figure $5 .{ }^{1} \mathrm{H}-\mathrm{NMR}$ spectrum of the sol fraction and simplified structure of hyperbranched polymer identified in the sol fraction of sample PU2-60.

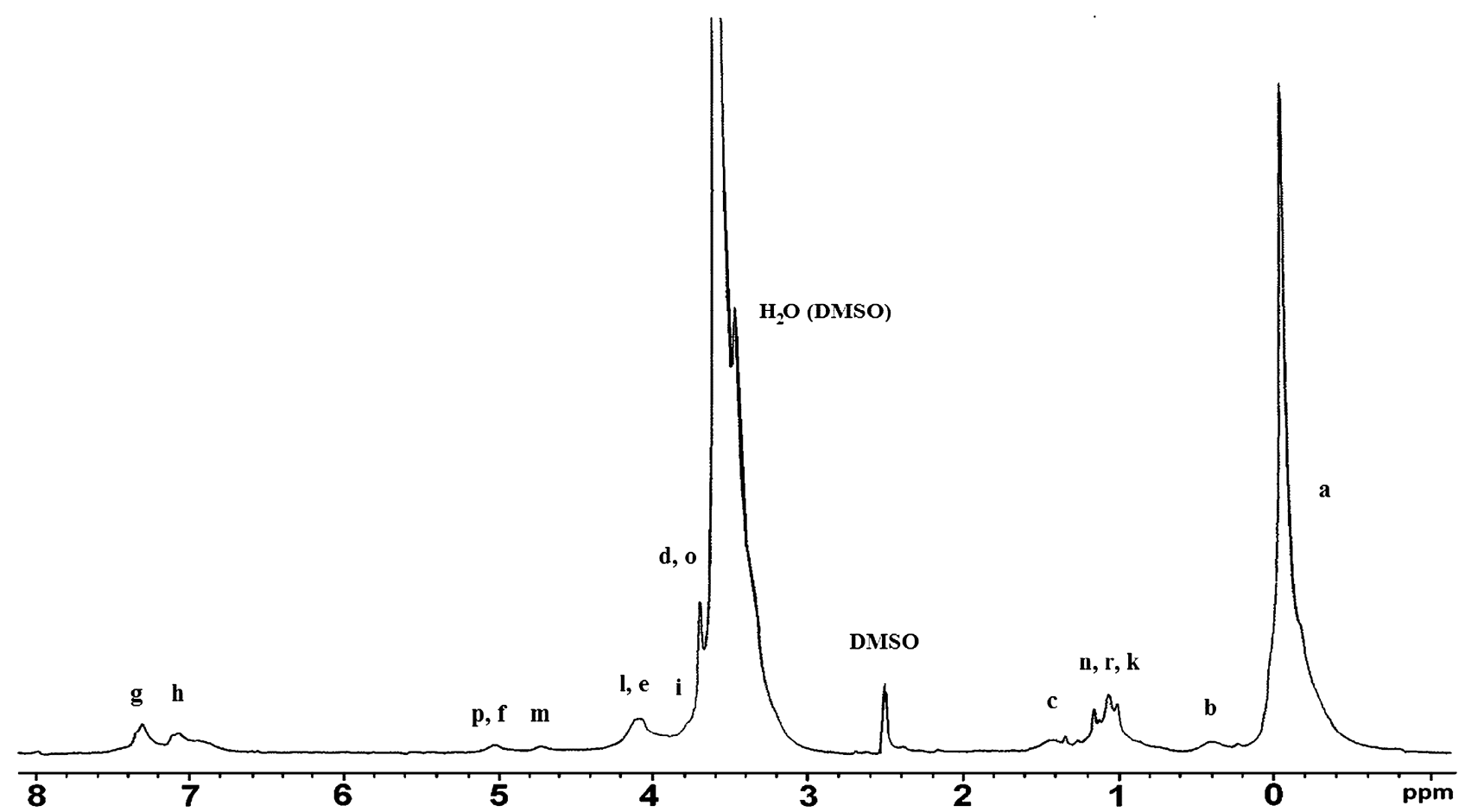

Figure $6 .{ }^{1} \mathrm{H}-\mathrm{NMR}$ spectrum of the sol fraction of sample PU2-30. 
indicate that certain amount of end -OH groups of hyperbranched polyester was left unreacted, probably due to the steric hindrance.

\section{CONSLUSIONS}

Polyurethane networks based on Boltorn ${ }^{\circledR}$ aliphatic hydroxy-functional hyperbranched polyester of the second pseudo generation, ethylene oxide-poly(dimethylsiloxane)-ethylene oxide and 4,4'-methylenediphenyl diisocyanate were synthesized. Six samples of different EO-PDMS-EO content were prepared, by two-step polymerization in solution.

The results obtained by FTIR spectroscopy confirmed the chemical structure of the polyurethanes and showed that all -NCO groups were used for the reaction. Swelling measurements, performed in 2-propanol and toluene indicate that the type of the solvent and the EO-PDMS-EO content have influence on the swelling behavior of the prepared PUs. During the swelling, sol fractions of the synthesized PUs were extracted from the samples by the used solvent. Equilibrium swelling degree of the examined polyurethanes and amount of the extracted sol fractions increase with increase of the EO-PDMS-EO content, indicating that samples with lower EO-PDMS-EO content are more cross-linked. ${ }^{1} \mathrm{H}$-NMR spectra of the sol fractions show that it is mainly composed of the soluble hyperbranched polyurethanes, formed by partial end-capping of $-\mathrm{OH}$ groups of HBP with NCO-terminated prepolymer, whose chains probably bended and formed cyclic products of different sizes by reaction of the free -NCO group with free $-\mathrm{OH}$ group of HBP.

\section{Acknowledgements}

This work was financially supported by the Ministry of Education and Science of the Republic of Serbia (Project No. 172062).

\section{REFERENCES}

[1] P. Czech, L. Okrasa, G. Boiteux, F. Méchin, J. Ulanski, Polyurethane networks based on hyperbranched polyesters: Synthesis and molecular relaxations, J. NonCryst. Solids 351 (2005) 2735-2741

[2] A.S. Nasar, M. Jikei, M. Kakimoto, Synthesis and properties of polyurethane elastomers crosslinked with amine-terminated $\mathrm{AB}_{2}$-type hyperbranched polyamides, Eur. Polym. J. 39 (2003) 1201-1208

[3] D. Lin, B. Liu, L. Xu, K.L. Budzinski, C. Shou, Synthesis of hyperbranched polyester-amides and their application as crosslinkers for polyurethane curing systems, J. Appl. Polym. Sci. 121 (2011) 957-963

[4] G. Prevec, E. Žagar, M. Žigon, Carboxylated polyurethanes containing hyperbranched polyester soft segments, Kem. Ind. 55 (2006) 365-372

[5] Q. Cao, L. Liao, H. Xu, Study on the influence of thermal characteristics of hyperbranched polyurethane phase change materials for energy storage, J. Appl. Polym. Sci. 115 (2010) 2228-2235

[6] J. Zhang, C.P. Hu, Synthesis, characterization and mechanical properties of polyester-based aliphatic polyurethane elastomers containing hyperbranched polyester segments Eur. Polym. J. 44 (2008) 3708-3714

[7] P.K. Maji, A.K. Bhowmick, Influence of number of functional groups of hyperbranched polyol on cure kinetics and physical properties of polyurethanes, J. Polym. Sci., A 47 (2009) 731-745

[8] J. Vuković, M. Pergal, S. Jovanović, V. Vodnik, Crosslinked polyurethanes based on hyperbranched polymers, Hem. Ind. 62 (2008) 353-359

[9] R. Adhikari, P.A. Gunatillake, S.J. McCarthy, G.F. Meijs, Mixed macrodiol-based siloxane polyurethanes: effect of the comacrodiol structure on properties and morphology, J. Appl. Polym. Sci. 78 (2000) 1071-1082

[10] H.-D.Hwang, H.-J. Kim, Enhanced thermal and surface properties of waterborne UV-curable polycarbonatebased polyurethane (meth)acrylate dispersion by incurporation of polydimethylsiloxane, React. Funct. Polym. 71 (2011) 655-665

[11] J. Vuković, M.D. Lechner, S. Jovanović, Rheological properties of concentrated solutions of aliphatic hyperbranched polyesters, Macromol. Chem. Phys. 208 (2007) 2321-2330

[12] J. Vuković, S. Jovanović, M.D. Lechner, V. Vodnik, in: J.N. Lee (Ed.), Modern Trends in Macromolecular Chemistry, Nova Science Publishers, New York, 2009, pp. 39-59

[13] M.V. Vuckovic, V.V. Antic, M.N. Govedarica, J. Djonlagic, Synthesis and characterization of copolymers based on poly(butylene terephthalate) and ethylene oxide-poly(dimethylsiloxane)-ethylene oxide, J. Appl. Polym. Sci. 115 (2010) 3205-3216

[14] M.V. Pergal, V.V. Antic, M.N. Govedarica, D. Gođevac, S. Ostojić, J. Djonlagic, Synthesis and characterization of novel urethane-siloxane copolymers with a high content of PCL-PDMS-PCL segments, J. Appl. Polym. Sci. 122 (2011) 2715-2730

[15] Å. Marand, J. Dahlin, D. Karlsson, G. Skarping, M. Dalene, Determination of technical grade isocyanates used in the production of polyurethane plastics, J. Environ. Monit. 6 (2004) 606-614

[16] E.A. Grulke, in: J. Brandrup, E.H. Immergut (Eds.), Polymer Handbook, $3^{\text {rd }}$ ed., Wiley, New York, Ch. 7, 1989, pp. 519-559

[17] M.V. Pergal, V.V. Antić, S. Ostojić, M. Marinović-Cincović, J. Djonlagić, Influence of the content of hard segments on the properties of novel urethane-siloxane copolymers based on a poly( $\varepsilon$-caprolactone)- $\beta$-poly(dimethylsiloxane)- $\beta$-poly( $\varepsilon$-caprolactone) triblock copolymer, J. Serb. Chem. Soc. J. Serb. Chem. Soc. 76 (2011) 1703-1723

[18] E. Žagar, M. Žigon, S. Podzimek, Characterization of commercial aliphatic hyperbranched polyesters, Polymer 47 (2006) 166-175

[19] E. Žagar, M. Žigon, Characterization of a commercial hyperbranched aliphatic polyester based on 2,2-bis(methylol)propionic acid, Macromolecules 35 (2002) $9913-$ -9925 . 


\title{
IZVOD
}

\section{SINTEZA I ISPITIVANJE BUBRENJA UMREŽENIH POLIURETANA NA BAZI HIPERRAZGRANATOG POLIMERA}

\author{
Jasna V. Džunuzović ${ }^{1}$, Marija V. Pergal ${ }^{1}$, Slobodan Jovanović ${ }^{2}$, Vesna V. Vodnik $^{3}$
}

${ }^{1}$ IHTM - Centar za hemiju, Univerzitet u Beogradu, Beograd, Srbija

${ }^{2}$ Tehnološko-metalurški fakultet, Univerzitet u Beogradu, Beograd, Srbija

${ }^{3}$ Institut za nuklearne nauke „Vinča", Beograd, Srbija

\section{(Naučni rad)}

Serija od šest uzoraka poliuretana je sintetisana polazeći od komercijalnog alifatskog Boltorn ${ }^{\circledR}$ hidroksi funkcionalnog hiperrazgranatog poliestra druge pseudo-generacije kao umreživača, $\alpha, \omega$-dihidroksi-(etilenoksid-poli(dimetilsiloksan)-etilenoksid) (EO-PDMS-EO) i 4,4'-metilendifenildiisocijanata primenom dvostepene polimerizacije u rastvoru. Svaki sintetisani uzorak umreženog poliuretana je imao različiti sadržaj EO-PDMS-EO. Hemijska struktura pripremljenih uzoraka poliuretana je analizirana FTIR spektroskopijom. Ispitan je uticaj sadržaja EO-PDMS-EO i vrste rastvarača (2-propanol i toluen) na svojstva sintetisanih umreženih poliuretana pri bubrenju. Prilikom bubrenja došlo je do izdvajanja sol frakcija iz sintetisanih uzoraka koje su nakon uparavanja rastvarača ispitane ${ }^{1} \mathrm{H}$ NMR spektroskopijom. Dobijeni rezultati ukazuju na to da se sol frakcija uglavnom sastoji od rastvornog hiperrazgranatog poliuretana nastalog $u$ toku reakcije polimerizacije kao posledica parcijalne modifikacije krajnjih hidroksilnih grupa hiperrazgranatog poliestra NCO-terminiranim pretpolimerom sintetisanim u prvom stupnju reakcije. Lanci tako proreagovalog pretpolimera su se najverovatnije zatim savili, pri čemu je došlo do dalje reakcije između preostale -NCO grupe sa nekom slobodnom -OH grupom iz hiperrazgranatog poliestra i formiranja ciklika, čime je određeni broj -NCO i-OH grupa blokiran za dalju reakciju umrežavanja. Pokazano je da stepen bubrenja i procenat sol frakcije sintetisanih uzoraka u oba rastvarača raste sa povećanjem sadržaja EO-PDMS-EO, što ukazuje da su uzorci sa nižim sadržajem EO-PDMS-EO više umreženi.

Ključne reči: Poliuretan • Hiperrazgranati poliestar • Poli(dimetilsiloksan) • Bubrenje 